\title{
Biosimilars: Current Scenario and Challenges in India
}

\author{
Anitha Nandagopal ${ }^{1 \star}$, Yusra Shakeel ${ }^{1}$, Mamatha Tirunagari ${ }^{2}$ \\ ${ }^{1}$ Department of Pharmacology, Sultan-ul-Uloom College of Pharmacy, Road No: 3, Banjara Hills, Hyderabad, Telangana \\ State, India. \\ ${ }^{2}$ Department of Pharmaceutics, Sultan-ul-Uloom College of Pharmacy, Road No: 3, Banjara Hills, Hyderabad, Telangana \\ State, India.
}

\begin{abstract}
For a long period of time, biologics have been a major part of the pharmaceutical sector in providing treatment for most complex diseases like cancer, Alzheimer's disease, etc. With their patent expiration, a wide scope of opportunities has been unleashed for their replication. For the low molecular weight biologics, generics are preferable and safe option, whereas the large sized biologics being inaccessible for their price have led to the introduction of a new genre of medicine, Biosimilar. Biosimilar is designed with the intent to treat a patient in the same way as an existing biologic therapy. They are not the exact replicas of their innovator drugs. They are derived protein having immunogenic reaction and risk of adverse events. Despite the hurdles, biosimilar offer promising beneficial and cost effective option, if allowed to be understood by physicians and patients.
\end{abstract}

Keywords: Biosimilar, biologics, generics, replicas, cost effective.

\section{INTRODUCTION}

The field of medicine has been able to achieve a new class of medicine, especially with the advancement in biotechnology ${ }^{1-2}$. These types of medicine are large sized molecules that are made in the bodies of living organisms by addition of DNA to cells. The cells further copy or translate this piece of DNA into a protein and thus a biologic medicine is created. In comparison to chemical generics these are about 200-1000 times larger in size ${ }^{3-5}$. These products being highly complexed in comparison to chemical drugs, are in fact polypeptides or glycoproteins or nucleic acids $^{6-7}$. Live cell lines are employed in the production of biologics which is why their reproduction is a difficulty. This is the reason biologics once manufactured are very hard to replicate exactly. The term biosimilar emphasize the difference

*Corresponding author: Prof. Anitha Nandagopal, e-mail: anirajan_76@yahoo.co.in (Received 22 September 2017, accepted 23 October 2017) 
in two products, similar to the innovator biologics but not their exact copy. In the past few years a number of biopharmaceutical patents have expired including granulocyte colony stimulating factors [G-CSFs], erythropoietin, interferons and human growth hormone. This has given way to the production of Biosimilar. When compared to their innovator biologics, few structural differences were found but however were clinically insignificant for consideration. Biosimilar, have the liberty to not undergo the same gruesome approval procedures as biologics which reflects in its cost, but in comparison to generic drugs they are still costlier ${ }^{8-9}$.

\section{Biologics-characteristics, significance and use}

Biologics is a term to refer to the most developed and significant area of biotechnological products that include viruses, allergenic, somatic cells, blood products, tissues, gene therapy and recombinant therapy proteins. With biologics, some of the milestones in therapeutic medicine that were not thought to be achieved are now in existence that include production of proteins with a special set of functions (e.g., fligrastim) and monoclonal antibodies that can target specific molecules (e.g., adalimumab) ${ }^{10}$.

The foundation of biologic medicines lies in recombinant DNA technology, which involves genetically engineering a cell that is an intricate, sensitive process and often specific to a particular medicine. The quality and efficacy of the biopharmaceutical at the final production stage depends on various factors such as, type of expression system, e.g. bacteria, yeast and mammalian cells, growth conditions offered, purification processes, storage and transport protocols undertaken. During cell synthesis, certain modifications are bound to occur such as, glycosylation, phosphorylation, sulphation, methylation, acetylation and hydroxylation which can alter the therapeutic potential of the drug. Such modifications need to be calculated as they can be the reason for production of a million variants of drugs ${ }^{11}$.

Biologics are very sensitive to factors such as temperature and $\mathrm{pH}$, which makes them hard to characterize and produce on large scale. Any minor modifications may lead to alteration in characteristics and change in structure, stability or other qualities of the final product. These have the possibility to affect the treatment safety, efficacy and shelf life and also increase the risk of immunogenic reactions.

In the present time, some of the most important medicines are biologics which include albumin, monoclonal antibodies, human insulin used for burns or liver failure, cancer and diabetes respectively.

Some other biologics include cloned proteins that occur naturally and erythropoietin in treatment of chronic anemia by stimulation of red blood cell production. In the treatment of some very critical conditions like cancer, rheumatoid 
arthritis (RA), psoriasis and multiple sclerosis biologics have been observed to be most effective ${ }^{12}$.

\section{Biosimilar}

Biosimilar can be said to be the latest biopharmaceutical agent that are 'similar' but in many aspects cannot be considered 'identical' to its reference product. They are synonymously also called Subsequent Entry Biologics (SEB) and Follow on Biologics.Post expiration of the patent(s) for these primarily approved biopharmaceuticals, other biotech and pharma companies acquire the chance to copy and market these biological drugs. These along with generic medicines can prove cost effective for patients and other sectors of society.

Biologic medicines exhibit both structural and molecular complexity. For the development and manufacture of high quality Biosimilar an intrinsic scientific knowledge and manufacturing expertise is required. Initially a cell line is chosen for the production of right clone. Thorough understanding of reference drug and its pharmacodynamics are the major criteria for Biosimilar development.

A Biosimilar is required to show similarity with reference biologic on the basis of:

1. Analytical (testing in a lab for structural/physical similarity),

2. Non-clinical (testing for function/activity/toxicity) and

3. Clinical data (testing in humans for safety and efficacy) in terms of structural characteristics, safety and efficacy.

\section{How similar are biosimilar to biologics?}

Biosimilar are not generic alternatives of innovator drugs nor can they be the exact duplicates of their innovator product. A Biosimilar and its reference cannot be entirely identical due to their differing manufacturing processes, but to qualify the approval process the protein sequence has to be same and structural alterations to a minor extent can be accepted ${ }^{13-15}$. It is critical to understand the differences and to demonstrate that they are not clinically meaningful and thus can be expected to be as safe and effective as the reference product for that approved condition of use.

The explicit details of the manufacturing processes employed in innovator drug production are a patented source and not always accessible. Thus, for Biosimilar to be exactly duplicated as their reference protein is impossible. Also the fact remains that detecting the protein characteristics require stringent analytical techniques, lack of which makes a thorough study of biopharmaceutical product difficult. Thus, regulatory guidelines have to be abided and pharmacovigilance is mandatory. 
Although innovator biologic products and Biosimilar are both proteins by nature, they both tend to possess immunogenic potential. However Biosimilar can have more adverse drug reaction episodes of the immunogenicity type than reference products as they do not go through the exact same regulatory approval when compared to innovator drugg ${ }^{16}$.

\section{Biosimilar versus generics ${ }^{17-18}$}

A generic drug is a chemically and therapeutically equivalent entity of a low molecular weight drug whose patent has expired. Biologics and Biosimilar are produced from live cells. On the other hand small molecule drugs and generics are produced by chemical / synthetic method. These discrepancies show that Biosimilar are not equal to generics. For a better understanding, the significant differences that exist between biologics and traditional small-molecule drugs in terms of basic chemical structure and manufacturing processes should be studied.

Chemical generics are small but well-defined molecules that can be generalized as chemical structures that are stable by nature. On the other hand, biopharmaceuticals are large peptides or proteins that have complex structural makeup. They are primarily made of amino acid sequence that should correspond to the traditional pharmaceutical. They have a three-dimensional structure which is highly sensitive to a lot of factors and need care while handling.

A finished generic drug can undergo chemical analysis to identify its various components whereas it is not just difficult but sometimes impossible to characterize a biologic and identify its components in a laboratory which explains its unique nature for many of its features may remain unknown.

\section{Manufacturing differences between Biosimilar and generics ${ }^{19-20}$}

Generic low molecular weight drugs are synthesized chemically by a combination of known reagents or ingredients in a series of controlled and predictable reactions. Biopharmaceuticals or Biosimilar are prepared in a living system that also secretes many other substances other than the required protein.

Therefore, generics can be replicated in an exact manner and they achieve an atomically identical structure to the reference drug. Biologics being complex will exhibit some physical and chemical differences. The variation in the production processes will also bring about some modifications (e.g. purification methods, post-traditional modification as glycosylation or sialylation, tertiary or quaternary structures) ${ }^{21}$. Apart from the above two major differences, there also exist some other characteristic differences that are listed below in Table 1. 
Table 1. Characteristic differences between generics and biosimilar

\begin{tabular}{|l|l|l|}
\hline Property & Generics & Biosimilar \\
\hline Molecular weight & $<500-900$ Daltons & $>140,000$ Daltons \\
\hline Manufacture & $\begin{array}{l}\text { Synthesized in laboratory } \\
\text { or extracted from natural } \\
\text { sources }\end{array}$ & $\begin{array}{l}\text { Manufactured from genetic material } \\
\text { of living cell cultures or DNA } \\
\text { technologies }\end{array}$ \\
\hline $\begin{array}{l}\text { Adverse immune } \\
\text { reaction }\end{array}$ & $\begin{array}{l}\text { Lower potential and } \\
\text { predictable }\end{array}$ & Higher potential and unpredictable \\
\hline Composition & $\begin{array}{l}\text { Active ingredients that are } \\
\text { identical to the innovator } \\
\text { product }\end{array}$ & $\begin{array}{l}\text { Active proteins or peptides that is not } \\
\text { identical but similar to innovator drug } \\
\text { to a questionable extent. }\end{array}$ \\
\hline $\begin{array}{l}\text { Approval } \\
\text { requirements }\end{array}$ & $\begin{array}{l}\text { Small clinical trials mostly } \\
\text { in healthy volunteers }\end{array}$ & $\begin{array}{l}\text { Phase } 3 \text { onwards extensive clinical } \\
\text { trials in patients. }\end{array}$ \\
\hline
\end{tabular}

\section{Development of Biosimilar}

The development of Biosimilar is a highly skilled, multi-step process that requires extensive understanding of the reference drug product. The multi-step process involved in the assessment and creation of a Biosimilar are given as follows.

\section{Creating and Producing a Biosimilar}

Transfect living cells with DNA



Produce the amino acid sequence of the biologic for each new clone

Thousands of versions of the biologic are created, each by a different clone

Evaluation and identification of the most similar clone to that of reference product.
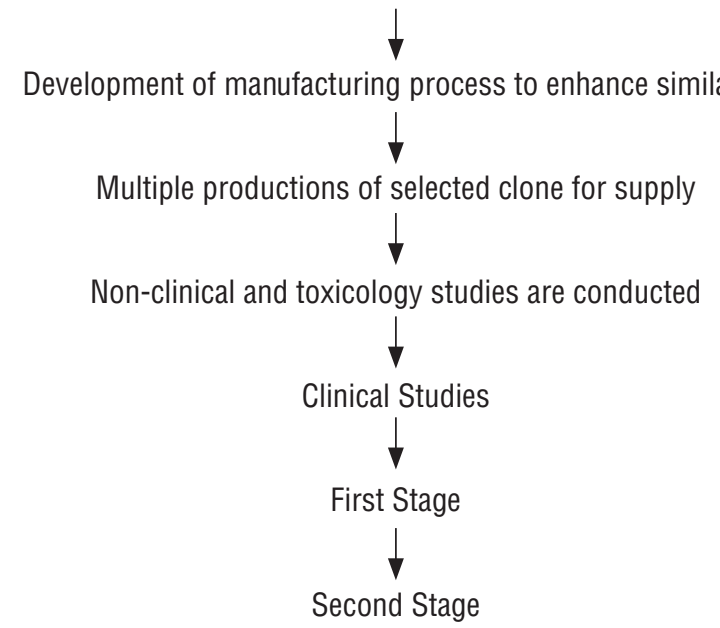


\section{Clinical studies}

A first stage in healthy volunteers or patients to test that the body processes the biologic in the same way as the reference product and,

A second stage in patients to test that the Biosimilar works with similar level of efficacy and safety as a reference product.

\section{Comparison between the reference product and biosimilar}

Lab testing and clinical testing of drug on patients are performed for bringing out a comparative study of the Biosimilar produced to its reference product. However there still exists an insufficient analytical testing system that lacks the ability to predict certain activity or safety reactions in patients.

\section{Challenges in biosimilar development}

The complex and variable nature of biologics and biosimilar presents numerous challenges for manufacturers and also the regulatory bodies such as European Medicines Agency (EMA) and U.S. Food and Drug Administration (FDA) and New India Guidelines that are responsible for approval process ${ }^{22-24}$. Several such issues include as follows.

\section{Naming and labeling}

Each Biosimilar medicine has given a unique and easily recognizable International Non-proprietary Name (INN). This naming program is recommended majorly by WHO with the intention to identify a drug by its active pharmaceutical ingredients. This name is a public property and can avoid confusion among prescribers, pharmacists or dispensers. Pharmacovigilance becomes easy by reporting the specific name of the medicine in case of an adverse event. Substitution should be avoided for both biologics and Biosimilar as this can lead to a delayed adverse event reporting because substitution leads to lack of traceability and tracking of the drug dispensed.

\section{Safety and efficacy issues / Immunogenicity}

The large molecular weight and size along with its complex nature, makes the immune system within a body recognize the biologic medicine, giving way to the possibility of a range of immunologic responses. This can result in consequences affecting the efficacy (neutralizing antibodies) and may give rise to anaphylactic or infusion reactions ${ }^{25}$.Small changes in any of the production steps of biosimilar can be a reason for alternations in cell behavior and can eventually affect the structural detailing or quality of the product. These changes can in turn disturb the shelf life of the products by interfering with its safety and efficacy, also possibly causing an immune response. Differences in age, gender and subsequent medicines taken can also affect patient response and needs consideration ${ }^{26}$. 


\section{Quality issues}

The manufacturing methods of Biosimilar have concerns about the quality and standards. The manufacturing method for a biosimilar should have the same quality requirements as any new biologic manufacturers and show that their process can produce a high-quality product. The method must include the scientific knowledge by which Biosimilar manufacturer may have access to advanced processes in comparison to the ones used for older originator products.

\section{Substitution issues}

The rulings and purpose for substituting biosimilar is different than generics. Generic drugs chemically synthesized can be substituted with their original drugs because they are identical, have the same therapeutic effect and are cost effective. However, in the case of biosimilar such irrational substitution can lead to adverse events and even failure of the intended therapy. This information is significant for a pharmacist and prescriber because a pharmacist can substitute a prescribed reference drug with a biosimilar or vice versa. In case of an adverse event, lack of accuracy in the documentation of the product dispensed to the patient can prove a hassle in pharmacovigilance assessment.

\section{Issues related to regulatory approval}

Adequate data of safety and efficacy of post animal and human study, pharmacovigilance and risk management data have to be submitted by the innovator companies and biosimilar producers to the US FDA and EMA for their approval. According to FDA biosimilar guidance announced by US FDA on February $9^{\text {th }}$, 2012, there exist lists of factors that need to be considered to demonstrate similarity of a biosimilar product to its reference drug. These include an intrinsic understanding of the manufacturing processes, mechanism of action, pharmacodynamics as well as pharmacokinetic studies including the immunogenicity potential and comparison of structural features of the two. Biosimilar do not undergo very extensive clinical trials but have to submit relevant data to be considered equivalent to a reference drug in terms of safety and clinical efficacy.

\section{Pharmacovigilance}

All biologic medicines, including Biosimilar, present at least some risk of an unwanted immune response to the medicine, where the patient reacts against the proteins in the medicine. The timely reporting of this and other adverse events is important. The difference that exists in Biosimilar inherently could be the cause for adverse events that might get overlooked at the time of Biosimilar approval.

In the pre-marketing period only a fixed number of patients receive the product which is why a very profound or rather extensive pharmacovigilance program is 
required for distinguishing immunogenic reaction episodes. Standard methods for detection of immunogenic reactions should be adapted. Lack of validated methods may not give information about the extent of adverse reaction and their management. The ADR monitoring should include complete details of the drug received, whether a reference or Biosimilar, proprietary name and International Non-proprietary Name (INN) along with the exact dosage administered ${ }^{27}$.

\section{Biosimilar in India}

Biosimilar in India are defined as: "A biological product/drug produced by genetic engineering techniques and claimed to be 'similar' in terms of quality, safety, and efficacy to a reference innovator product, which has been granted a marketing authorization in India by a competent authority on the basis of a complete dossier, and with a history of safe use in India ${ }^{28}$.

Here are few factors that facilitate the development and uptake of Biosimilar in India.

- Patent enforcements undertaken by manufacturing companies are guarded by poor laws that give opportunities for domestic biologic manufacturers and private sector partnerships to promote Biosimilar development.

- There are less strict regulatory requirements and low R\&D costs, domestic biologics are priced much lower in India compared to originators.

- The low price of Biosimilar compared to originator brands is restricted by limited health insurance coverage and therefore there still exists poor access to biologic drugs.

- Issues regarding the quality and safety of some domestically manufactured Biosimilar and lack of patient education remain a concern among patients and physicians $^{29-30}$.

\section{Indian regulations and guidelines on biosimilar production}

In June 2012, the Department of Biotechnology (DBT) has announced The New India Guidelines, "Draft Guidelines on Similar Biologics: Regulatory Requirements for Marketing Authorization in India." These guidelines mention the regulatory pathway for a similar Biologic to declare to be similar to an already existing Reference Biologic.

The guidelines mention regarding manufacturing process, safety and efficacy and quality aspects for similar biologics. The guidelines also mention the premarket regulatory requirements along with comparability exercise for quality, preclinical and clinical studies and post market regulatory needs for Similar Biologics. 
The Similar Biologics are regulated as per the Drugs and Cosmetics Act, 1940, the Drugs and Cosmetics Rules, 1945 (as amended from time to time) and Rules for the manufacture, use, import, export and storage of hazardous microorganisms / genetically engineered organisms or cells, 1989 (Rules, 1989) notified under the Environment (Protection) Act, 1986.

Various applicable guidelines are as follows:

- Recombinant DNA Safety Guidelines, 1990

- Guidelines for generating preclinical and clinical data for rDNA vaccines, diagnostics and other Biologicals, 1999

- CDSCO guidance for industry, 2008:

- Submission of Clinical Trial Application for Evaluating Safety and Efficacy

- Requirements for permission of New Drugs Approval

- Post approval changes in Biological products: Quality, Safety and Efficacy Documents

- Preparation of the Quality Information for Drug Submission for New Drug Approval: Biotechnological/Biological Products

- Guidelines and Handbook for Institutional Biosafety Committees (IBSCs), 2011

- Guidelines on Similar Biologics: Regulatory Requirements for Marketing authorization in India 2012

\section{Competent Authorities in the Approval Process of Biosimilar}

\section{a) Institutional Biosafety Committee (IBSC)}

A person in any research institution who is handling the hazardous microorganisms and / or genetically altered organisms need to constitute the IBSC. The main objective of IBSC is to ensure the biosafety and review the applications to be recommended to RCGM. It is also responsible to review and authorize firm for exchange of the above-mentioned organisms for the purpose of research.

\section{b) Review Committee on Genetic Manipulation (RCGM)}

The main role of RCGM is to authorize import / export for research and development, exchange of genetically modified organisms for the purpose of research and development and review of data up to preclinical screening.

\section{c) Genetic Engineering Appraisal Committee (GEAC)}

Under the Ministry of Environment and Forests (MOEF) the GEAC works as a statutory body to review the research proposals and approve the activities for the 
final drug product which contains the genetically modified organisms / living modified organisms.

\section{d) Central Drugs Standard Control Organization (CDSCO)}

The main function of CDSCO is to grant the import / export license, clinical trial approval and giving permission for marketing and manufacturing. The State Food and Drug Administration works along with CDSCO for issuing the licenses to the manufacturer of similar biologic in India. Import of drugs for examination, test and analysis for research and development is done by zonal CDSCO.

\section{Factors that favor and withhold biosimilar use in India}

Various factors contribute in the development and uptake of Biosimilar in India. These include:

- Poor patent enforcement in India provides opportunities to obtain approval for domestically manufactured Biosimilar that are ruling the Indian Biologics market.

- Less stringentregular requirements, lack of monitoring of laws and low R\&D costs promotes Biosimilar development. Phase 1-2 clinical trials are not required for copying biologics if pharmaco-equivalence is proved whereas phase 3 trials can be performed on equal to or less than 100 patients. Also Biosimilar development takes approximately 8 years in the Europe, it only takes $3-5$ years in India for a copy biologic. For Indian Biosimilar industry cost is a major advantage. In India to manufacture a Biosimilar molecule it need of US $\$ 10$ to 20 million when compared to developed countries which need US $\$ 50$ to 100 million. It shows that in India there is nearly 40\% reduction in cost which makes it attractive place for Biosimilar manufacture ${ }^{31-32}$.

- Due to low development and manufacturing costs, domestic biologic manufacturers are able to sell their products at a heavy discount in the range $12-74 \%$ in comparison to the original drug that is sold in Indian market. Such discounting forces the originators to reduce their price to retain their market share.

- Domestic and foreign companies owing to the commercial opportunity are trying to enter into the market of biosimilar. However, these companies face a major drawback for successfully developing, manufacturing and commercializing Biosimilar. This has drawn partnership as a solution. Such mutually beneficial collaborations help the source company with experience and resources whereas the partnering company benefits by establishing itself in the biologics market.

- However, if such drivers of development exist, on the other hand there are certain reasons that become resistors in the path of Biosimilar development. Some such are:

a) Low affordability of the comparatively expensive Biosimilar/biologics due to 
lack of health insurance is a major drawback for obtaining therapeutic benefit. So majority of the patients fail to afford such expensive treatment options.

b) The physicians still hesitate to prescribe Biosimilar as an alternate to biologics. Moreover, there has been noticeable difference in the potency between several Indian Biosimilar compared to their reference products. Manufacturing processes being different introduces impurities that can pose a threat to the final product. In order to minimize the risk of immunogenicity prescribers often avoid any such substitution ${ }^{33-34}$. The Biosimilar which are produced in India after the amendment of "Similar Biologic guidelines" were shown in Table 2.

Table 2. Biosimilars produced in India after "Similar Biologics Guideline" which came into effect on 15 September 2012 29-31

\begin{tabular}{|c|c|c|c|c|}
\hline Product name & Active substance & Therapeutic area & $\begin{array}{l}\text { Approval/ } \\
\text { launch } \\
\text { date } \\
\text { in India }\end{array}$ & Company \\
\hline AbcixiRel & Abciximab & $\begin{array}{l}\text { Angina, Cardiac } \\
\text { ischemia }\end{array}$ & Apr-13 & $\begin{array}{l}\text { Reliance Life } \\
\text { Sciences }\end{array}$ \\
\hline Actorise & Darbepoetin alfa & $\begin{array}{l}\text { Anaemia, Cancer, } \\
\text { Chronic kidney failure }\end{array}$ & Jan-14 & Cipla/Hetero \\
\hline Adfrar & Adalimumab & $\begin{array}{l}\text { Ankylosing spondylitis, } \\
\text { Plaque psoriasis, } \\
\text { Psoriatic arthritis, } \\
\text { Rheumatoid arthritis, } \\
\text { Ulcerative colitis }\end{array}$ & Jan-16 & $\begin{array}{c}\text { Torrent } \\
\text { Pharmaceuticals }\end{array}$ \\
\hline Bevacirel & Bevacizumab & Colorectal cancer & Jun-16 & $\begin{array}{c}\text { Reliance Life } \\
\text { Sciences (Lupin) }\end{array}$ \\
\hline CanMab & Trastuzumab & Breast cancer & Oct-13 & Biocon \\
\hline Cizumab & Bevacizumab & Colorectal cancer & Jun-16 & Hetero \\
\hline Darbatitor & Darbepoetin alfa & $\begin{array}{l}\text { Anaemia, Cancer, } \\
\text { Chronic kidney failure }\end{array}$ & 2014 & $\begin{array}{c}\text { Torrent } \\
\text { Pharmaceuticals }\end{array}$ \\
\hline Etacept & Etanercept & $\begin{array}{c}\text { Ankylosing spondylitis, } \\
\text { Rheumatoid arthritis, } \\
\text { Psoriatic arthritis, } \\
\text { Psoriasis, Juvenile } \\
\text { rheumatoid arthritis }\end{array}$ & Apr-2013 & Cipla \\
\hline Exemptia & Adalimumab & Rheumatoid arthritis & Sep-14 & Zydus Cadila \\
\hline Filgrastim & Filgrastim & Neutropenia & 0ct-13 & $\begin{array}{c}\text { Cadila } \\
\text { Pharmaceutical }\end{array}$ \\
\hline Filgrastim & Filgrastim & Neutropenia & Mar-13 & Lupin \\
\hline
\end{tabular}




\begin{tabular}{|c|c|c|c|c|}
\hline Product name & Active substance & Therapeutic area & $\begin{array}{l}\text { Approval/ } \\
\text { launch } \\
\text { date } \\
\text { in India }\end{array}$ & Company \\
\hline Folisurge & $\begin{array}{l}\text { Follitropin } \\
\text { alfa (follicle } \\
\text { stimulating } \\
\text { hormone) }\end{array}$ & $\begin{array}{l}\text { Female infertility, } \\
\text { Spermatogenesis in } \\
\text { men }\end{array}$ & May-13 & $\begin{array}{c}\text { Intas } \\
\text { Pharmaceuticals }\end{array}$ \\
\hline Infimab & Infliximab & $\begin{array}{l}\text { Ankylosing spondylitis, } \\
\text { Crohn's disease, } \\
\text { Psoriasis, Psoriatic } \\
\text { arthritis, Rheumatoid } \\
\text { arthritis, Ulcerative } \\
\text { colitis }\end{array}$ & Sep-14 & $\begin{array}{c}\text { Epirus } \\
\text { Biopharmaceuticals }\end{array}$ \\
\hline Intacept & Etanercept & $\begin{array}{l}\text { Ankylosing spondylitis, } \\
\text { Juvenile idiopathic } \\
\text { arthritis Psoriasis, } \\
\text { Psoriatic arthritis, } \\
\text { Rheumatoid arthritis }\end{array}$ & Mar-15 & $\begin{array}{c}\text { Intas } \\
\text { Pharmaceuticals }\end{array}$ \\
\hline MabTas & Rituximab & $\begin{array}{l}\text { Lymphoma, Non- } \\
\text { Hodgkin's Lymphoma }\end{array}$ & Feb-13 & $\begin{array}{c}\text { Intas } \\
\text { Pharmaceuticals }\end{array}$ \\
\hline Molgramostim & $\begin{array}{c}\text { Recombinant } \\
\text { human } \\
\text { granulocyte } \\
\text { macrophage } \\
\text { colony } \\
\text { stimulating factor } \\
\text { (molgramostim) }\end{array}$ & Neutropenia & May-13 & $\begin{array}{l}\text { Zenotech } \\
\text { Laboratories }\end{array}$ \\
\hline Peg-filgrastim & Pegfilgrastim & Cancer, Neutropenia & Sep-13 & Lupin \\
\hline $\begin{array}{l}\text { Peg-interferon } \\
\text { alfa } 2 b\end{array}$ & $\begin{array}{c}\text { Pegylated } \\
\text { recombinant } \\
\text { human interferon } \\
\text { alfa } 2 b\end{array}$ & $\begin{array}{l}\text { Chronic hepatitis B, } \\
\text { Chronic hepatitis C }\end{array}$ & Apr-13 & $\begin{array}{c}\text { Intas } \\
\text { Pharmaceuticals }\end{array}$ \\
\hline Rasburicase & Rasburicase & $\begin{array}{l}\text { Malignancy associated } \\
\text { hyperuricemia }\end{array}$ & Aug-12 & Virchow Biotech \\
\hline Rituximab & Rituximab & $\begin{array}{c}\text { Non-Hodgkin's } \\
\text { Lymphoma, Rheumatoid } \\
\text { arthritis }\end{array}$ & Feb-15 & $\begin{array}{l}\text { Reliance Life } \\
\text { Sciences }\end{array}$ \\
\hline Teriparatide & $\begin{array}{l}\text { Teriparatide } \\
\text { (parathyroid } \\
\text { hormone) }\end{array}$ & $\begin{array}{l}\text { Post-menopausal } \\
\text { women with } \\
\text { osteoporosis who are at } \\
\text { high risk for fracture }\end{array}$ & Aug-12 & Cadila Healthcare \\
\hline Wosulin & Human insulin & Diabetes mellitus & Aug-03 & Wockhardt \\
\hline
\end{tabular}




\section{CONCLUSION}

The recent expiration of patents for some important biologics have given a ray of hope to the biosimilar manufacturers. As these products are proteins, their safety and efficacy will always be considered a concern that should require stringent analysis and pharmacovigilance. Awareness between biosimilar and innovator products in terms of safety, efficacy and immunogenicity is essential for effective prescription and safety of the patients. India the leading producer of biosimilar should frame effective guidelines, nomenclature regulations and proper pharmacovigilance program.

\section{CONFLICT OF INTEREST}

There is no conflict of interest between the authors.

\section{ACKNOWLEDGEMENT}

The authors are grateful to Sultan-ul-Uloom education Society for providing us the facility to carry out the research work.

\section{REFERENCES}

1. Alamchandani, R.R.; Sattigeri, B.M.; Karelia, P.S. Biologics and biosimilars: Role in modern pharmacotherapy and importance of pharmacovigilance. Int. J. Res. Med. Sci. 2014, 2, 382-386.

2. Guilford-Blake, R.; Strickland, D. Guide to Biotechnology. Biotechnology Industry Organization. 2008. www.bio.org/sites/default/files/ BiotechGuide2008.pdf. Accessed January 24, 2013, 2.

3. Amgen, Biologics and Biosimilars: An Overview. 1st ed. Amgen, 2015.

4. Thomas, M.D.; Linda, H.F. Defining the difference: What makes biologics unique? Biotechnology healthcare. 2004, 1(4), 24-29.

5. Chaudhary, P. The Impact of Rheumatoid Arthritis and Biologics on Employers and Payers. Biotechnology Healthc. 2008, 5(2), 37-44.

6. Igor, A.; Kaltashov; Cedric, E. B.; Shunhai Wang. Advances and challenges in analytical characterization of biotechnology products: mass spectrometry-based approaches to study properties and behavior of protein therapeutics. Biotechnol Adv. 2012, 3o(1), 210-222.

7. Sekhon, B.S.; Saluja, V. Biosimilars: an overview. Biosimilars. 2011, 1, 1-11.

8. Mellstedt, H. Niederwiese D.; Ludwig, H. The challenge of biosimilars. Annals of Oncology. 2008, 19(3), 411-419.

9. European Medicines Agency. Guideline on similar biological medicinal products containing biotechnology-derived proteins as active substance: quality issues (revision 1), 2012.

10. Majidi, J.; Barar, J.; Baradaran, B.; Abdolalizadeh, J.; Omidi, Y. Target therapy of cancer: implementation of monoclonal antibodies and nanobodies. Hum Antibodies. 2009, 18(3), 81-100.

11. Crommelin, D.; Bermejo, T.; Bissig, M.; Damiaans, J.; Kramer, I.; Ramboug P. et al. Pharmaceutical evaluation of biosimilars: important differences from generic low-molecular-weight pharmaceuticals. Eur. J. Hosp. Pharm. Sci. 2005, 11(1), 11-17.

12. Avidor, Y.; Mabjeesh, N.J.; Matzkin, H. Biotechnology and drug discovery: from bench to 
bedside. Southern. Med. J. 2003, 96(12), 1174-1186.

13. Cork, S., M. Interpreting biological similarity: ongoing challenges for diverse decision makers. Michigan Telecommunications and Technology Law Review. 2013, 19(2), 423-460.

14. Schellekens, H.; Ryff, J.C. 'Biogenerics': the off-patent biotech products. Trends in Pharmacological Sciences, 2002, 23(3), 119-121.

15. Weise M.; Bielsky, M.C.; De Smet, K.; Ehmann, F.; Ekman, N.; Giezen, T.J. et al. Biosimilars: what clinicians should know? Blood. 2012, 120(26), 5111-5117.

16. Europa Bio Guide to biological medicines: a focus on biosimilar medicines, 2011.

17. Walter J., Jeanine M. W., Debra H., Jawed F. Update on the safety and bioequivalence of biosimilars - focus on enoxaparin. Drug Healthc Patient Saf. 2013, 5, 133-141.

18. Geigert, J. The Challenge of CMC Regulatory Compliance for Biopharmaceuticals and Other Biologics, Springer Science+Business Media New York.2013, 21-33.

19. Jayaraman, K. India's Cipla sets sights on Avastin, Herceptin and Enbrel. Nature. Biotechnol. 2010, 28(9), 883-884.

20. Generics and Biosimilars Initiative. Similar biologic approved and launched in India. 2012.

21. Kuhlmann, M.; Covic, A. The protein science of biosimilars. Nephrol. Dial. Transplant. 2006, 21(5), 4-8.

22. James, G.; Stevenson. Clinical Data and Regulatory Issues of Biosimilar products, The American Journal of Managed care. 2015, 21(16), 320-330.

23. U.S. Food and Drug Administration: Biosimilars: Questions and Answers Regarding Implementation of the Biologics Price Competition and Innovation Act of 2009. 2012.

24. Government of India, Department of Biotechnology, Ministry of Science and Technology, Central Drugs Standard Control Organization, Ministry of Health and Family Welfare: Guidelines on Similar Biologics: Regulatory Requirements for Marketing Authorization in India. 2012. 25. Purcell, R.T.; Lockey, R.F. Immunologic responses to therapeutic biologic agents. J. Investig. Allergol. Clin. Immunol. 2008, 18(5), 335-342

26. Monika, M. Biosimilars: Current perspectives and future implications, Indian. J. Pharmacol. 2012, 44(1): 12-14.

27. Nowicki, M. Basic facts about Biosimilars. Kidney Blood Press Res. 2007, 30(5), 267-72.

28. Bhairav B. A., Saudagar R. B., Gondhkar S. B., Dipak M. D., Neha V. N. Biosimilars: global scenario and challenges. International Journal of Biopharmaceutics. 2014, 5(1), 19-28.

29. Ariyanchira, S. The Opportunity for India in the Global Biosimilars Market. Pharmaphorum, 2010.

30. Desai J.P. "Bridges to Bloom: The Future of Indian Biosimilars" by Universal Consulting India (Pvt) Ltd., September 2009.

31. Subramaniam, K.V. India as a global leader in biosimilars, a presentation at the Biosimilars India Conference. 2011, 14-15 July Mumbai, India.

32. Bourgoin, A. What you need to know about the follow-on biologic market in the US: Implications, strategies and impact - competitive landscape. 2011.

33. Tandon, V.R.; Mahajan, A.; Khajuria, V.; Kapoor, V. Biologics and challenges ahead for the physicians. JIACM. 2006, 7(4), 334-343.

34. Mody, R. et al. How similar are biosimilars in India? Pharmafocus. Asia. C2004-2012 Ochre media. 